\title{
Potential Effects of a Species' Name
}

\author{
Tomasz Skawiński
}

Published online: 9 March 2012

(C) Springer Science+Business Media, LLC 2012

\begin{abstract}
In systematics, the importance of a species' name is obvious and very considerable - it may even affect the names of other taxa (genera and families). Here, I argue that in some specific circumstances the name of a species may also indirectly play some role in the public understanding of the theory of evolution and creationism - or at least, has the potential to play such a role.
\end{abstract}

Keywords Names · Creationism · Media · Poland ·

Population thinking $\cdot$ Smok wawelski

In August 2011, a new species of archosaur reptile, Smok wawelski, was described in an online article in the journal Acta Palaeontologica Polonica. ${ }^{1}$ It was a big animal of about five to six meters in length that lived in the Late Triassic, about 205 million years ago, in what is now southern Poland. The phylogenetic position of the species is controversial - it was first considered a theropod dinosaur, possibly even an early tetanuran (member of a group that includes well-known gigantic theropods such as Tyrannosaurus and Allosaurus, as well as birds), but more recent research suggests that it might be not a dinosaur but a rauisuchian - a reptile more closely related to crocodiles than to dinosaurs (Niedźwiedzki et al. 2012). However, it is not only the animal's relationships that provoked such considerable debate.

\footnotetext{
${ }^{1}$ According to the International Code of Zoological Nomenclature, the name "Smok wawelski" is not yet available because the article has not yet been published on paper (International Commission on Zoological Nomenclature 1999).
}

T. Skawiński $(\bowtie)$

Wrocław, Poland

e-mail: tomasz.skawinski@o2.pl
The name Smok wawelski derives from the dragon of Polish folklore - the Wawel dragon (Smok Wawelski in Polish). According to the legend, the Wawel dragon lived in a cave on Wawel Hill in Cracow when Krak was king. The dragon was killed by two of Krak's sons or, in a later version, Skuba the shoemaker. The legend is very well known in Poland, and everyone there knows the name Smok Wawelski. So the fossil archosaur, discovered in Lisowice (about $150 \mathrm{~km}$ from Cracow), gained the tentative name of smok ("dragon") or "smok z Lisowic" ("dragon from Lisowice") even before the discovery was officially announced in August 2008 (Mikołuszko 2008).

The 2011 publication was overlooked by the popular English-language literature, but it gained great popularity in Poland; there was wide news coverage announcing that the "first Polish dinosaur has been described." Some news stories facetiously announced (even in headlines) that "the Wawel dragon really lived in Poland" (Informacyjna Agencja Radiowa 2011) or "the Wawel dragon, symbol of Cracow, really existed" (Chojnowska 2011). Jacek Majchrowski, president of Cracow, commented, "thanks to that discovery, the legend became truth" (Chojnowska 2011). Such claims were made because many of the Mesozoic extinct archosaurs (such as $S$. wawelski) are roughly similar to our notions of Dragons. This similarity may have very real implications: none would claim that, for example, the trilobite Han solo is "proof" that Han Solo (a character from Star Wars) really existed.

Incidentally, Maciej Giertych, a plant physiologist and a politician, also known for his antievolutionist activities (Graebsch 2006; Borczyk 2010), has said that the Wawel dragon legend is one of the pieces of evidence that dinosaurs (that is, non-avian dinosaurs) and humans coexisted in the past, thereby disproving evolution (Giertych 2006; Kazikiewicz 2007). Despite being deliberately facetious, some phrases from such stories in the popular press 
may create a false impression that Giertych was right after all about the Wawel dragon - and thus provide unexpected support to the claims of creationists. This may happen especially when some sentences are deliberately removed from the wider context - we know creationists have frequently done that in the past (e.g., Matzke 2010). Moreover, it has been noted that even a small number of creationists can cause a lot of confusion (e.g., Forrest and Gross 2007). Kids, in particular, are threatened by this kind of disinformation - lots of them are interested in mythical creatures like dragons, so they may readily uncover news that "dragons really lived" and believe it, especially because this information is based on a real scientific discovery made by respected scientists. This is why evolutionists should also be active on the Internet and unmask creationists' lies as well as counter other incorrect or exaggerated statements (e.g., Switek 2010) and propagate proper understanding of evolution. This may be especially important given the fact that fantastic (and also often incorrect or manifestly false) claims tend to attract the most attention (Sagan 1996). Particularly important areas of such activity may be question-and-answer websites such as Ask A Biologist, where most of the questions are posed by kids (Hone et al. 2011).

The situation described above shows that - in some cases (e.g., in a particular country or particular language) - an atypical and rather unexpected indirect effect of naming species may arise. The long-term effects of such species names are so far unknown.

Acknowledgements I thank Rafał Skrzatek (Wrocław) for help with the access to the literature and Barbara Royle, Robin Royle (Wrocław) and Evolution: Education and Outreach editor(s) for the linguistic improvements to the manuscript.

\section{References}

Borczyk B. Creationism and the teaching of evolution in Poland. Evol Educ Outreach. 2010;3:614-20. doi:10.1007/s12052-010-0292-3.

Chojnowska A. Prezydent dziękuje za smoka wawelskiego [President thanks for the Wawel dragon]. Gazeta.pl. 2011. http://krakow. gazeta.pl/krakow/1,44425,10169633,Prezydent_dziekuje_za_ smoka_wawelskiego.html. Accessed 5 Jan 2012 (in Polish).

Forrest BC, Gross PR. Biochemistry by design. Trends Biochem Sci. 2007;32:301-10. doi:10.1016/j.tibs.2007.06.001.

Giertych M. Creationism, evolution: nothing has been proved. Nature. 2006;444:265. doi:10.1038/444265d.

Graebsch A. Polish scientists fight creationism. Nature. 2006;443:890 1. doi: $10.1038 / 443890$ c.

Hone DWE, Taylor MP, Wynick D, Viscardi P, Gostling N. Running a question-and-answer website for science education: first hand experiences. Evol Educ Outreach. 2011;4:153-7. doi:10.1007/ s12052-011-0318-5.

Informacyjna Agencja Radiowa. W Polsce naprawdę żył smok wawelski [The Wawel dragon really lived in Poland]. Polskie Radio Szczecin. 2011. http://www.radio.szczecin.pl/index. php?idp $=6 \&$ szukaj $=\& s=\& i d x=75724$. Accessed 5 Jan 2012 (in Polish).

International Commission on Zoological Nomenclature. International code of zoological nomenclature. 4th ed. London: International Trust for Zoological Nomenclature; 1999.

Kazikiewicz M. Giertych: Merkel działa jak Hitler [Giertych: Merkel acts like Hitler]. Życie Warszawy. 2007. http://www.zyciewarszawy.pl/ artykul/206154.html. Accessed 5 Jan 2012 (in Polish).

Matzke NJ. The evolution of creationist movements. Evol Educ Outreach. 2010;3:145-62. doi:10.1007/s12052-010-0233-1.

Mikołuszko W. Potwór z Lisowic [Monster from Lisowice]. Natl Geogr (Polish edition). 2008;8:2-19 (in Polish).

Niedźwiedzki G, Sulej T, Dzik J. A large predatory archosaur from the Late Triassic of Poland. Acta Palaeontol Pol. 2012. doi:10.4202/ app.2010.0045 (in press).

Sagan C. The demon-haunted world. New York: Ballantine; 1996. p. 73-6.

Switek BJ. Ancestor or adapiform? Darwinius and the search for our early primate ancestors. Evol Educ Outreach. 2010;3:468-76. doi:10.1007/s12052-010-0261-x. 